\section{Molecular aspects during seed germination of Erythrina velutina Willd. under different temperatures (Part 1): reserve mobilization}

\author{
Francival Cardoso Felix ${ }^{1}$ iD, Josenilda Aprígio Dantas de Medeiros $^{1}{ }^{(\mathbb{D}}$, Cibele \\ dos Santos Ferrari ${ }^{1} \mathbb{D}$, Mauro Vasconcelos Pacheco ${ }^{1^{*}}$, Salvador Barros \\ Torres $^{2}$ iD
}

ABSTRACT: Erythrina velutina Willd. (Fabaceae) is a tree species that bears social, ecological, and economic importance for northeastern Brazil, a region with frequent temperature variations. The objective of this work was to evaluate the mobilization of reserves during seed germination and seedling establishment of $E$. velutina at different temperatures, and how these mechanisms are affected in a thermal-stress situation. The seeds germinated at $5,15,25,35$, and $45^{\circ} \mathrm{C}$, and the physiological and biochemical aspects of reserve mobilization (starch, lipids, and total proteins) were assessed during seedling establishment. Germination, vigor, and the mobilization of reserves from the cotyledons to the embryonic axis are affected according to the incubation temperature. The temperature of $25^{\circ} \mathrm{C}$ favors the mobilization of reserves during seed germination and seedling establishment in $E$. velutina. In a situation of thermal stress, high temperatures affect the establishment of the seedlings, whereas low temperatures compromise the mobilization of reserves.

Index terms: germination ecophysiology, reserve compounds, seed biochemistry, semiarid, thermal stress.

Aspectos moleculares durante a germinação de sementes de Erythrina velutina Willd. sob diferentes temperaturas (Parte 1): mobilização de reservas

RESUMO: Erythrina velutina Willd. (Fabaceae) é uma espécie arbórea de importância social, ecológica e econômica para o Nordeste do Brasil, região com frequentes variações da temperatura. O objetivo deste trabalho foi avaliar a mobilização de reservas durante a germinação de sementes e estabelecimento de plântulas de $E$. velutina em diferentes temperaturas, e como esses mecanismos são afetados em situações de estresse térmico. As sementes foram colocadas para germinar a 5, 15, 25, 35 e $45^{\circ} \mathrm{C}$, e os aspectos fisiológicos e bioquímicos de mobilização de reservas (amido, lipídios e proteínas totais) foram avaliados durante o estabelecimento das plântulas. A germinação, o vigor e a mobilização de reservas dos cotilédones para o eixo embrionário são afetados de acordo com a temperatura de incubação das sementes de $E$. velutina. A temperatura de $25{ }^{\circ} \mathrm{C}$ favorece a mobilização de reservas durante a germinação de sementes e estabelecimento de plântulas de $E$. velutina. Em situações de estresse térmico, altas temperaturas prejudicam o estabelecimento de plântulas, enquanto baixas temperaturas afetam negativamente a mobilização de reservas.

Termos para indexação: ecofisiologia da germinação, compostos de reserva, bioquímica de sementes, semiárido, estresse térmico.
Journal of Seed Science, v.42, e202042029, 2020

http://dx.doi.org/10.1590/ 2317-1545v42239839
${ }^{*}$ Corresponding author
E-mail: pachecomv@hotmail.com

Received: 6/19/2020

Accepted: 7/20/2020.

${ }^{1}$ Unidade Acadêmica Especializada em Ciências Agrárias, Universidade Federal do Rio Grande do Norte (UFRN), Distrito de Jundiaí, 59280000, Macaíba, Rio Grande do Norte, Brasil.

${ }^{2}$ Departamento de Ciências Agronômicas e Florestais, Universidade Federal Rural do Semiárido (UFERSA), 59625-900, Mossoró, Rio Grande do Norte, Brasil. 


\section{INTRODUCTION}

Erythrina velutina Willd. (Fabaceae) is a xerophyte tree, native to northeastern Brazil (Rodrigues et al., 2018), and found in the phytogeographic domains of the Caatinga and Cerrado. This non-endemic species occurs isolated or in dense groups, and has its seed dispersion associated with floodplains (Melo et al., 2015). Currently, its frequency has been dwindling in the Brazilian semiarid region, even facing the risk of extinction due to indiscriminate exploitation (Alves-Júnior et al., 2016). For that reason, studies on the propagation of this plant are of great importance.

In nature, the surrounding conditions for seed germination and seedling establishment are often adverse. Consequently, the process of reserve mobilization and metabolism regulation of the plant can suffer alterations due to abiotic stresses (Silva et al., 2019). Temperature is one of the abiotic factors that regulate biochemical mechanisms of seeds (Gonçalves et al., 2015; Reis et al., 2020; Santos et al., 2020), as well as physiological responses during germination, which activate adaptive strategies to environment stresses (Tesfay et al., 2016).

Studies on the optimal temperature for the germination of forest-native species are vital for estimating the responses of adaptation (Correa et al., 2020) and propagation in situations of thermal stress, and their possible environmental consequences. This kind of investigation is particularly important in a scenario of global warming, which might lead to plant extinction due to metabolic changes (Santos et al., 2020). In order to better understand the propagation strategies and mechanisms of these species, research on the physiology and biochemistry of seeds is paramount to elucidate which the main reserve compounds are, and how they are mobilized during the processes of germination and establishment of the seedlings (Ataíde et al., 2017).

Seedling establishment culminates in the transition from a heterotrophic phase to an autotrophic one, when the first photosynthetic organs reach full development (Bewley et al., 2013). This process depends on the mobilization of stored reserves (from cotyledons and endosperm) and the translocation of soluble metabolites to the embryonic axis (Silva et al., 2019). These accumulated macromolecules are used as a source of energy and carbon for seed germination and seedling development (Erbaş et al., 2016).

Non-reducing sugars (sucrose and oligosaccharides, such as raffinose, stachyose, and verbascose), cell-wall polysaccharides (galactomannans, glucomannans, and xyloglucans), and starches are the primary reserve carbohydrates mobilized, together with storage lipids (triacylglycerols) and reserve proteins (albumins, prolamines, and globulins) (Bewley et al., 2013; Soriano et al., 2015; Zhang et al., 2020). In conjunction and at different quantities, depending on the species and environmental conditions to which they are exposed (Zhao et al., 2018; Önder et al., 2020), these biomolecules deliver the energy required to initiate seed germination and seedling establishment, thus supplying the new plant with carbon and nitrogen until the autotrophic phase (Marcos-Filho, 2015).

In simple terms, carbohydrates and lipids undergo enzymatic hydrolysis, generating glucose derivatives, which are used to produce energy and carbon skeletons for the anabolism of new molecules. Amino acids resulting from protein catabolism provide mainly nitrogen, which is employed as an energy source and for the construction of several essential biomolecules (Bewley et al., 2013). Therefore, the way these compounds are degraded directly affects the establishment of forest-species seedlings.

On that account, the objective of this study was to evaluate the mobilization of reserves during seed germination and seedling establishment of $E$. velutina at different temperatures, and also how these mechanisms are affected in a thermal-stress situation. The tested hypotheses are based on the following questions: 1 ) does temperature affect seed germination and mobilization of reserves during the establishment of E. velutina seedlings?; 2) which temperature is more favorable?; 3 ) which temperatures cause stress during this stage?

\section{MATERIAL AND METHODS}

The study utilized E. velutina seeds lots from the city of Ilhéus, state of Bahia, Brazil. They were purchased (> 70\% 
viability) in 2017 and kept under refrigeration at $4{ }^{\circ} \mathrm{C}$, until the execution of the experiment. Before anything else, the seeds had their moisture content determined by the oven method at $105^{\circ} \mathrm{C}$ for $24 \mathrm{~h}$, in two subsamples of $4.5 \mathrm{~g}$ (Brasil, 2009). The results were expressed in percentage.

\section{Seed germination}

The germination tests were carried out with four replications of 50 seeds each. They used paper towel (Germitest ${ }^{\circ}$ ) as the substrate, which was moistened with distilled water at the proportion of three times the paper dry weight (Brasil, 2009). The seeds were scarified with sandpaper in the region opposite to the micropyle and then sown between the paper sheets. Next, the paper rolls containing the seeds were kept in Biochemical Oxygen Demand (BOD) germinators set at $5,15,25,35$, and $45^{\circ} \mathrm{C}$, and a 12 -hour photoperiod.

The following variables were appraised: percentage of normal and abnormal seedlings at each incubation temperature (Brasil, 2009); germination speed, obtained by the daily count of germinated seeds and calculated according to the formula proposed by Maguire (1962); average length of the primary root and shoot of normal seedlings, measured with a millimeter ruler and expressed in $\mathrm{cm}^{\text {seedling }}{ }^{-1}$. Ultimately, the morphological changes in the seedling structures during the establishment at the different temperatures were withal described.

\section{Reserve mobilization}

The determination of the compounds in the cotyledons (starch, total proteins, and lipids) and the partition of biomass at the different stages of development $(0-$ dry seed, I - primary root protrusion, II - root-hypocotyl differentiation, III - separation of the cotyledons, and IV - expansion of the primary leaves) were obtained from seeds that germinated under the same conditions described for the germination test, at temperatures of 15,25 , and $35^{\circ} \mathrm{C}$ (200 seeds each).

Starch: the total soluble sugars were previously removed with $80 \%$ ethanol (v/v), at $60^{\circ} \mathrm{C}$ for $30 \mathrm{~min}$, in hermetically sealed tubes. Then, the starch was quantified through the anthrone reaction, based on the hydrolytic and dehydrating action of concentrated sulfuric acid on carbohydrates (McCready et al., 1950, Dubois et al., 1956). For that purpose, three replications of $300 \mathrm{mg}$ of cotyledons were macerated with $30 \%$ perchloric acid $\left(\mathrm{HClO}_{4}\right)(\mathrm{v} / \mathrm{v})$. Then, the samples were centrifuged at $10,000 \times \mathrm{g}$ for $40 \mathrm{~min}$ at $4{ }^{\circ} \mathrm{C}$. Subsequently, they were quantified by the anthrone method, with a spectrophotometer at a 620-nanometer wavelength. The results were ultimately expressed in mg.cotyledon ${ }^{-1}$.

Lipids: they were evaluated by the gravimetric method, using $\mathrm{n}$-hexane as a solvent (Soxhlet, 1879). Three 0.5-gram replications of cotyledon dry weight were ground and incubated in a water bath at $60^{\circ} \mathrm{C}$ for $5 \mathrm{~h}$. After that, they were dried in an oven for $48 \mathrm{~h}$ and weighed on an analytical balance $(0.001 \mathrm{~g})$. The results were expressed in mg.cotyledon ${ }^{-1}$.

Total proteins: three 0.5 -gram samples of cotyledon dry weight were subjected to the Kjeldahl methodology. This technique determines the total nitrogen content of a sample by displacing this element from ammonia salts, and subsequently converting it into ammonium by digestion, neutralization, and distillation. Finally, a titration is carried out to attain the total nitrogen amount (Hoehne et al., 2016). Based on these results, the total nitrogen was converted into the approximate protein content of the sample, and the results were expressed in mg.cotyledon ${ }^{-1}$.

The dry weight measurements of the seeds, cotyledons, and roots and shoot of the seedlings, and embryo were carried out in four replications with three parts. The structures were dried in an oven at $60^{\circ} \mathrm{C}$ for $72 \mathrm{~h}$, and weighed on an analytical balance $(0.001 \mathrm{~g})$. The results were expressed in $\mathrm{mg}^{\text {. part }}{ }^{-1}$.

\section{Statistical analysis}

The experiment was carried out in a completely randomized design. The analysis of variance (ANOVA) and the comparisons of means by Tukey's test considered a 5\% probability level. The statistical analyses were performed with the software BioEstat ${ }^{\circ}$ 5.0. 


\section{RESULTS AND DISCUSSION}

The $E$. velutina seeds had $6.1 \%$ moisture content at the time of the experiment, a percentage similar to that of other native species, such as Amburana cearensis (Allemão) A.C.Sm. (5.6\%), Myracrodruon urundeuva Allemão (9.6\%), Schinopsis brasiliensis Engl. (7.5\%), and Sideroxylon obtusifolium Roem. \& Schult. (8.9\%) (Oliveira et al., 2014). This fact reinforces the evidence that orthodox seeds of Brazilian forest species from the semiarid get dispersed from the parent plant with low water content.

Both seed germination and vigor expression of E. velutina seedlings were directly affected by the incubation temperature. The seeds of this species were favored by a temperature of $25{ }^{\circ} \mathrm{C}(86 \%)$ but displayed significant germination losses when incubated at $15{ }^{\circ} \mathrm{C}(38 \%)$ and $35{ }^{\circ} \mathrm{C}(19 \%)$ (Table 1). The seeds submitted to 5 or $45{ }^{\circ} \mathrm{C}$ did not germinate. At $45{ }^{\circ} \mathrm{C}$, there was no physiological activity corresponding to root protrusion due to the death of the seeds. In turn, the temperature of $5{ }^{\circ} \mathrm{C}$ induced seed quiescence (low metabolism) - although they were still capable of germinating when placed at $25^{\circ} \mathrm{C}$.

Seed germination occurs only within a minimum and maximum temperature limits, with the ideal value being that at which the maximum germination is obtained the fastest (Bewley et al., 2013; Marcos-Filho, 2015; Correa et al., 2020). Ambient conditions between 20 and $30{ }^{\circ} \mathrm{C}$ are indicated for seed germination of several tropical and subtropical forest species (Silva et al., 2016; Ataíde et al., 2017; Benedito et al., 2019). In those circumstances, deterioration reactions due to high temperatures $\left(45^{\circ} \mathrm{C}\right)$ do not take place during germination, thus preventing metabolism changes, cell damages (membrane degradation), and alterations in essential biomolecules, remarkably nucleic acids (DNA deterioration), lipids (lipid peroxidation), and proteins (protein denaturation and enzyme inactivation) (Bewley et al., 2013; Önder et al., 2020).

M. urundeuva seeds showed the highest germination at $20^{\circ} \mathrm{C}$, whereas the temperature of $30^{\circ} \mathrm{C}$ was more suitable for A. cearensis, S. brasiliensis, and S. obtusifolium (Oliveira et al., 2014). The temperatures of 25 and $30{ }^{\circ} \mathrm{C}$ provided superior germinative performance in seeds of Dimorphandra mollis Benth. (Pacheco et al., 2010), Myroxylon balsamum (L.) Harms (Loayza-Cabezas et al., 2018), and Melanoxylon brauna Schott. (Santos et al., 2020). These observations indicate that semiarid species have different optimal temperature requirements for seed germination.

More abnormal seedlings were formed at $35^{\circ} \mathrm{C}(57 \%)$, followed by $15{ }^{\circ} \mathrm{C}(40 \%)$, and $25{ }^{\circ} \mathrm{C}(6 \%)$ (Table 1$)$. The germination speed was lower in seeds exposed to $15^{\circ} \mathrm{C}(4.3)$, and the seedlings submitted to 15 and $35^{\circ} \mathrm{C}$ expressed less vigor, as appraised by the length of their root and shoot systems (Table 1). The incubation temperature directly influences the occurrence and speed of biochemical reactions in the seeds. The effects can be more or less significant, to a certain extent, according to the increase or decrease of the germination temperature, respectively (Bewley et al., 2013). This causes considerable changes in the enzymatic activity, metabolism, imbibition, reserve mobilization, and synthesis of compounds necessary for the seedlings (Santos et al., 2020).

Table 1. Germination, abnormal seedlings, germination speed, and length of the root and shoot of Erythrina velutina seedlings at different temperatures.

\begin{tabular}{|c|c|c|c|}
\hline \multirow{2}{*}{ Variable } & \multicolumn{3}{|c|}{ Temperature $\left({ }^{\circ} \mathrm{C}\right)$} \\
\hline & 15 & 25 & 35 \\
\hline Germination (\%) & $38 \mathrm{~b}$ & $86 a$ & $19 \mathrm{c}$ \\
\hline Abnormal seedlings (\%) & $40 \mathrm{~b}$ & $6 c$ & $57 a$ \\
\hline Germination speed & $4.3 \mathrm{~b}$ & $13.5 \mathrm{a}$ & $13.9 \mathrm{a}$ \\
\hline Root length (cm.seedling ${ }^{-1}$ ) & $3.9 \mathrm{~b}$ & $12.7 \mathrm{a}$ & $2.9 \mathrm{~b}$ \\
\hline Shoot length (cm.seedling ${ }^{-1}$ ) & $6.0 c$ & $18.2 \mathrm{a}$ & $9.4 b$ \\
\hline
\end{tabular}

Means followed by the same letter, in the row, are statistically equal, according to Tukey's test at a $5 \%$ probability level. 
Higher temperatures (from 20 to $30^{\circ} \mathrm{C}$ ) boost the metabolic rate and accelerate the hydrolysis and mobilization of seed reserves by the activity of catalytic enzymes (amylases, lipases, and proteases, for example). These phenomena increase the speed of the chemical reactions included in the germinative metabolism. On the other hand, seeds vulnerable to low temperatures during the initial hydration phase deliver a reduced germination percentage, little growth, and low seedling productivity (Tesfay et al., 2016).

The germination test proved that the morphologically and physiologically superior and most vigorous seedlings originated from E. velutina seeds submitted to $25{ }^{\circ} \mathrm{C}$. Conversely, the temperatures of 15 and $35{ }^{\circ} \mathrm{C}$ limited the adequate development of structures essential for the establishment of the seedlings, mostly those related to the length of the roots and shoot. They also provoked the discoloration of the photosynthetic apparatus and damaged the root system (Figure 1).

During the germination of the $E$. velutina seeds, at all temperatures considered, there was a partition of the biomass of the cotyledons for the establishment of the seedlings (Figures $2 \mathrm{~A}, 2 \mathrm{~B}$, and $2 \mathrm{C}$ ). Nonetheless, the highest investment in both root system and shoot occurs at $25^{\circ} \mathrm{C}$ (Figure $2 \mathrm{~B}$ ), thus forming more vigorous seedlings (Figure 1 ). Moreover,

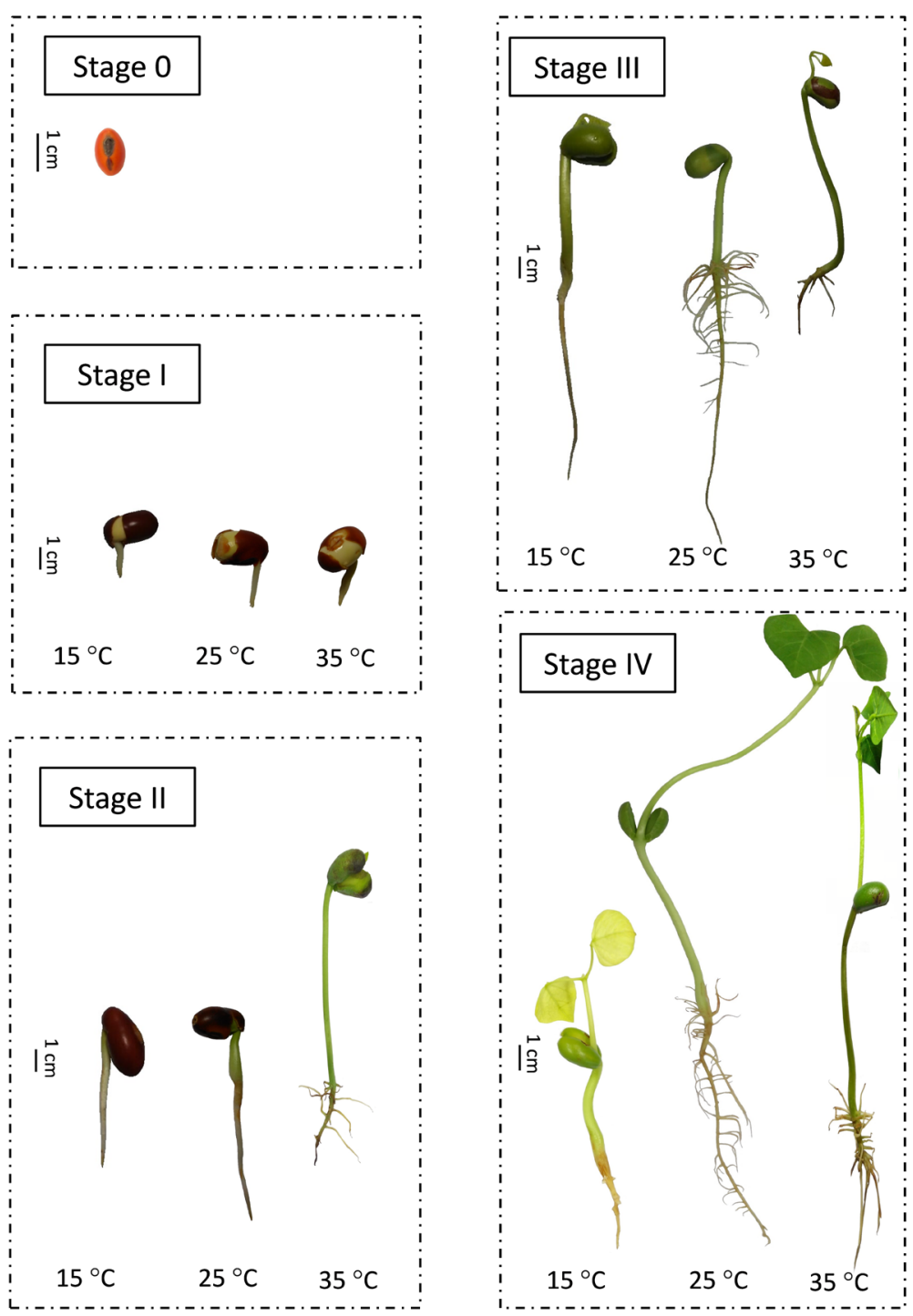

Figure 1. Stages of development of Erythrina velutina seedlings originated from seeds germinated at different temperatures: 0 - dry seed, I - primary root protrusion, II - root-hypocotyl differentiation, III - separation of the cotyledons, and IV - expansion of the primary leaves. 
there was a proportional increased of the shoot dry weight in relation to the biomass loss of the cotyledons. This indicates that the dry weight partition from the cotyledon to the shoot was more efficient at $25^{\circ} \mathrm{C}$ than at 15 or $35^{\circ} \mathrm{C}$ (Figures 2A, 2B, and 2C).

At the temperature of $15{ }^{\circ} \mathrm{C}$, the seedlings had a slow development, presenting morphological characteristics similar to those exposed to $25^{\circ} \mathrm{C}$, until stage III. However, in stage IV, the seedlings exhibited chlorosis in the primary leaves, hypocotyl, and epicotyl, and were withal smaller than their counterparts formed at 25 and $35{ }^{\circ} \mathrm{C}$ (Figure 1 ). These variances in morphology are linked to the partition of dry weight. Also because of that, in stage IV, the shoot showed little biomass increment at $15^{\circ} \mathrm{C}$ (Figure $2 \mathrm{~A}$ ).

Seedlings that grew at $35{ }^{\circ} \mathrm{C}$ showed rapid development of their structures at the beginning of the germination process (stages I and II) (Figure 1). Nevertheless, throughout germination, the cotyledons had a wilted appearance
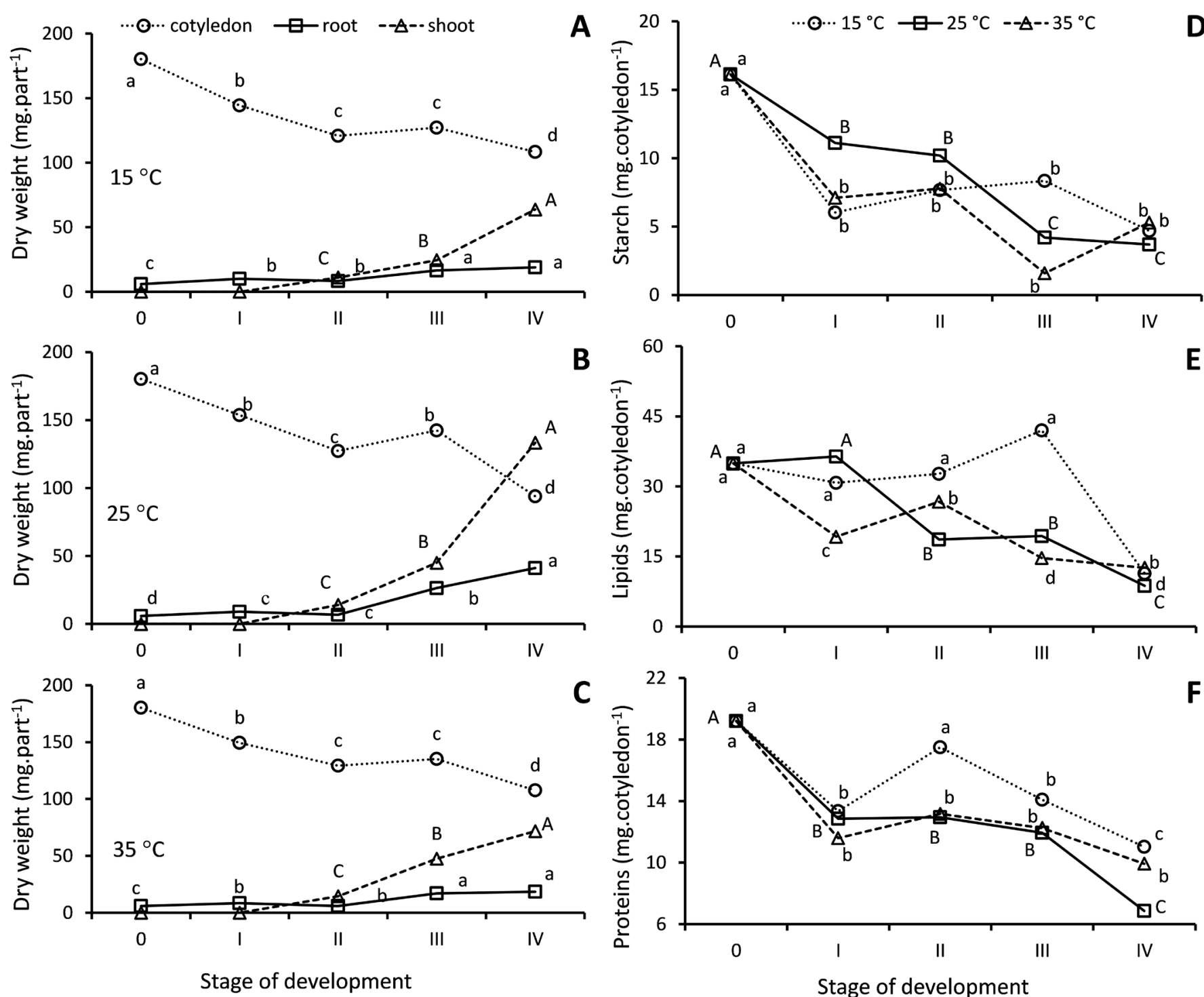

Figure 2. Biomass partition at $15^{\circ} \mathrm{C}(\mathrm{A}), 25^{\circ} \mathrm{C}(\mathrm{B})$, and $35^{\circ} \mathrm{C}(\mathrm{C})$, and mobilization of starch (D), lipids (E), and total proteins (F) during seeds germination and establishment of Erythrina velutina seedlings: 0 - dry seed, I - primary root protrusion, II - root-hypocotyl differentiation, III - separation of the cotyledons, and IV - expansion of the primary leaves. Means followed by the same letter, at each temperature, are statistically equal, according to Tukey's test at a $5 \%$ probability level. 
(low turgescence), and the main root developed less in stages III and IV (Figure 1). The few secondary roots that were produced exhibited signs of oxidation at the extremities, which caused a considerable formation of abnormal seedlings (57\%) (Table 1 ).

As the developmental stages progressed, the partition of the cotyledon biomass to embryonic axis growth during germination and seedling establishment tended towards the shoot, in detriment to the root system, at 15, 25, and $35{ }^{\circ} \mathrm{C}$ (Figures $2 \mathrm{~A}, 3 \mathrm{~B}$, and $3 \mathrm{C}$ ). At $25^{\circ} \mathrm{C}$, the root system showed an increase in the dry weight partition (Figure $2 \mathrm{~B}$ ), whereas the temperatures of 15 and $35{ }^{\circ} \mathrm{C}$ limited its growth in stages III and IV (Figures $2 \mathrm{~A}$ and $2 \mathrm{C}$ ). This probably owns to the fact that the most well-formed primary leaves of seedlings cultivated at $25{ }^{\circ} \mathrm{C}$ started to perform photosynthesis and, from then on, began to accumulate more dry weight.

The cotyledons of $E$. velutina seeds have $32.4 \%$ starch, $22.5 \%$ lipids, and $19.2 \%$ total proteins, which are the primary sources of energy reserves and carbon skeletons for germination and seedling establishment $(25.9 \%$ come from other compositions). After seeds are hydrated, the metabolism and respiration are activated, which mobilizes stored reserve compounds and provides energy for the embryo growth (Tesfay et al., 2016). The mobilization of cotyledon reserves to the embryonic axis of the $E$. velutina seeds during germination at different temperatures occurred continuously as the seedling development progressed (Figures 2D, 2E, and 2F). The consumption of the energy reserves (starch, lipids, and total proteins) evidenced the mobilization of the reserve compounds (source) and their translocation to other organs (drain).

Starch, lipids, and proteins within the seed storage tissues are hydrolyzed and then converted into sugar (sucrose) and amino acids (asparagine and glutamine). These simple compounds are soluble and mobile; therefore, they are available for plant growth and development (Bewley et al., 2013). Differences among seeds from distinct plant species depend on the reserves accumulated during maturation (Erbaş et al., 2016), and the characteristics of using these compounds under thermal stress affect both vigor and formation of new seedling tissues (Andrade et al., 2019).

Starch mobilization initiated between stages 0 and I, with some $49.9 \%$ reduction up from 16.1 mg.cotyledon ${ }^{-1}$. A higher degradation happened at $25{ }^{\circ} \mathrm{C}$ in the subsequent stages (77\%), while it maintained constant at 15 and $35{ }^{\circ} \mathrm{C}$ between stages I (6.55 mg.cotyledon ${ }^{-1}$ ) and IV (5.00 mg.cotyledon ${ }^{-1}$ ) (Figure 2D). It is worth mentioning that the seeds at $15^{\circ} \mathrm{C}$ reached stage I after six days, whereas it only took two days for the seeds at 25 and $35^{\circ} \mathrm{C}$ to do so. Therefore, the degradation noticed at this stage happened faster at $35^{\circ} \mathrm{C}\left(4.5 \mathrm{mg}\right.$.cotyledon ${ }^{-1}$. day $\left.{ }^{-1}\right)$ when compared to $25^{\circ} \mathrm{C}(2.50$ mg.cotyledon ${ }^{-1} \cdot$ day $\left.^{-1}\right)$ and $15^{\circ} \mathrm{C}\left(1.68 \mathrm{mg}^{\circ}\right.$ cotyledon ${ }^{-1}$.day $\left.{ }^{-1}\right)$. Finally, a more expressive starch degradation was registered at $25^{\circ} \mathrm{C}\left(0.69\right.$ mg.cotyledon ${ }^{-1}$.day $\left.{ }^{-1}\right)$, followed by $35^{\circ} \mathrm{C}\left(0.60 \mathrm{mg} \cdot\right.$ cotyledon $^{-1}$. day $\left.{ }^{-1}\right)$ and $15^{\circ} \mathrm{C}\left(0.44 \mathrm{mg}^{\circ} \operatorname{cotyledon}^{-1} \cdot\right.$ day $\left.^{-1}\right)$.

The total protein content also displayed a pattern of degradation at all temperatures, which was more efficient at $25{ }^{\circ} \mathrm{C}\left(0.68 \mathrm{mg}\right.$.cotyledon ${ }^{-1}$.day $\left.{ }^{-1}\right)$, followed by $35{ }^{\circ} \mathrm{C}\left(0.51 \mathrm{mg} \cdot\right.$ cotyledon $^{-1}$.day $\left.{ }^{-1}\right)$ and $15{ }^{\circ} \mathrm{C}\left(0.31 \mathrm{mg} \cdot\right.$ cotyledon $^{-1}$.day $\left.{ }^{-1}\right)$ (Figure 2F). In stage I, there was a $34.4 \%$ diminution in the total protein content of the cotyledons (19.2 mg.cotyledon ${ }^{-1}$ ). At the end of the seedling establishment (stage IV), the total protein levels dropped to $6.9 \mathrm{mg} \cdot \operatorname{cotyledon}^{-1}\left(25^{\circ} \mathrm{C}\right), 9.90$ mg.cotyledon ${ }^{-1}\left(35^{\circ} \mathrm{C}\right)$, and 11.0 mg.cotyledon $^{-1}\left(15^{\circ} \mathrm{C}\right)$.

M. brauna seeds also showed a significant depletion of carbohydrates and proteins in the cotyledons during germination at 25 and $30{ }^{\circ} \mathrm{C}$ (Ataíde et al., 2017), while higher temperatures triggered thermal stress and metabolic alterations (Santos et al., 2020). In the process, amylases and other enzymes break the starch within the granules in the cell plastids into smaller units, producing glucose and fructose. These compounds are converted into sucrose, which is transported by the phloem (Erbaş et al., 2016). These sugars are used for ATP production and as a carbon source that supplies the embryo demand and, consequently, forms new cells and promotes seedling growth (Lopes et al., 2013).

Reserve proteins, abundant in dicotyledons, are synthesized during seed maturation (Soriano et al., 2015) and hydrolyzed by proteases (endopeptidases, aminopeptidases, and carboxypeptidases). These enzymes catalyze the cleavage of peptide bonds by lowering the $\mathrm{pH}$ (introduction of $\mathrm{H}^{+}$ions) inside cell vacuoles that store protein. That way, they contribute to the synthesis of new molecules, essential for the growing seedling, by supplying them with amino acids (Bewley et al., 2013). Legumes have an advantage because they possess higher amounts of fixed nitrogen in their 
seed reserves (globulins), which play an essential role during germination, as they are the basis for the formation of new amino acids, proteins, and nucleic acids (Soriano et al., 2015). Besides, there is a positive correlation between the nitrogen content and seed germination rate in deciduous forest species (Soriano et al., 2011).

Regarding lipid degradation, the temperatures of $25^{\circ} \mathrm{C}\left(1.45\right.$ mg.cotyledon ${ }^{-1}$.day $\left.{ }^{-1}\right)$ and $35^{\circ} \mathrm{C}\left(1.24\right.$ mg.cotyledon ${ }^{-1}$. day $\left.^{-1}\right)$ were more efficient than $15{ }^{\circ} \mathrm{C}\left(0.90 \mathrm{mg} \cdot\right.$ cotyledon $^{-1} \cdot$ day $\left.^{-1}\right)$ - this last condition kept the lipid levels constant from stages 0 to III (35.1 mg.cotyledon ${ }^{-1}$ ). In stage IV, the lipid levels were $68.7 \%$ lower than at the beginning of the germination process (34.9 mg.cotyledon ${ }^{-1}$ ) (Figure 2E). Lipids correspond to the second largest reserve and, initially, they are not catabolized like starch and proteins, as they play an important role in the establishment of the seedlings until they become autotrophic (Hooks et al., 2010). Likewise, carbohydrates and proteins are prioritized during the germination of wild species, regardless of the chemical composition of their seeds (Zhao et al., 2018).

Lipids, in the form of triacylglycerols within the oleosomes of the cotyledon cells, are hydrolyzed by lipases. These enzymes catalyze the hydrolytic cleavage of ester bonds in fatty acids, producing free fatty acids and glycerol. These free fatty acids are then converted into oxaloacetic acid inside the glyoxysomes, via $\beta$-oxidation and the glyoxalate cycle. They also pass through the mitochondria and, in the cytosol, are converted into sucrose (gluconeogenesis). This sugar is transported via the phloem and supplies the growing embryonic axis with energy and carbon skeletons (Erbaş et al., 2016).

Similarly to what happened at $25{ }^{\circ} \mathrm{C}$, the degradation of the seed reserve compounds submitted to $35{ }^{\circ} \mathrm{C}$ was affected, in terms of both conversion rate and quantity. However, these compounds were used to a lesser extent for the formation of new tissues, as proved by the biomass results (Figure 2C). For that reason, in higher-temperature scenarios, the establishment of E. velutina seedlings is impaired, as most of the reserves go to respiration instead of being used for building new tissues. In contrast, low temperatures affect the metabolism of seeds during germination, culminating in the formation of less vigorous seedlings.

\section{CONCLUSIONS}

The temperature of $25^{\circ} \mathrm{C}$ favors the mobilization of reserves during the seed germination and establishment of $E$. velutina seedlings. In a situation of thermal stress, high temperatures hinder the establishment of seedlings, whereas low temperatures negatively affect the mobilization of reserves.

\section{ACKNOWLEDGEMENTS}

This study was supported by the Coordenação de Aperfeiçoamento de Pessoal de Nível Superior - Brazil (CAPES) Finance Code 001.

\section{REFERENCES}

ALVES-JÚNIOR, C.; VITORIANO, J.O.; SILVA, D.L.S.; FARIAS, M.L.; DANTAS, N.B.L. Water uptake mechanism and germination of Erythrina velutina seeds treated with atmospheric plasma. Scientific Reports, v.6, p.33722, 2016. https://doi.org/10.1038/srep33722

ANDRADE, G.C.; COELHO, C.M.M.; PADILHA, M.S. Seed reserves reduction rate and reserves mobilization to the seedling explain the vigour of maize seeds. Journal of Seed Science, v.41, n.4, p.488-497, 2019. https://doi.org/10.1590/2317-1545v41n4227354

ATAÍDE, G.M.; BORGES, E.E.L.; PICOLI, E.A.T.; LEITE-FILHO, A.T.; FLORES, A.V. Changes in seed reserves of Melanoxylon brauna Schott. (Fabaceae Caesalpinioideae) during germination at different temperatures. Brazilian Journal of Agricultural Sciences, v.12, n.3, p.372-379, 2017. https://doi.org/10.5039/agraria.v12i3a5454

BENEDITO, C.P.; RIBEIRO, M.C.C.; PAIVA, E.P.; MEDEIROS, H.L.S. Dormancy overcoming and germination test in Piptadenia stipulacea Benth. Ducke seeds. Revista Ciência Agronômica, v.50, n.2, p.338-344, 2019. https://www.scielo.br/scielo.php?pid=S180666902019000200338\&script=sci_arttext 
BEWLEY, J.D.; BRADFORD, K.J.; HILHORST, H.W.M.; NONOGAKI, H. Seeds: physiology of development, germination and dormancy. 3.ed. Nova York, EUA: SPRINGER, 2013. 392p.

BRASIL. Ministério da Agricultura, Pecuária e Abastecimento. Regras para análise de sementes. Ministério da Agricultura, Pecuária e Abastecimento. Secretaria de Defesa Agropecuária. Brasília, Brasil: MAPA/ACS, 2009. 395p. https://www.abrates.org.br/files/ regras_analise_de_sementes.pdf

CORREA, A.R.; SILVA, A.M.P.; SILVA, V.S.M.; CAMILI, E.C.; SILVA, A.R.B.; COELHO, M.F.B. Germination and seed ecology of Buchenavia tomentosa Eichler (Combretaceae). Journal of Seed Science, v.42, e202042007, 2020. https://doi.org/10.1590/2317-1545v42223782

DUBOIS, M.; GILLES, K.A.; HAMILTON, J.K.; REBERS, P.A.; SMITH, F. Colorimetric method for determination of sugars and related substances. Analytical Chemistry, v.28, n.3, p.350-356, 1956. https://doi.org/10.1021/ac60111a017

ERBAŞ, S.; TONGUÇ, M.; KARAKURT, Y.; ŞANLI, A. Mobilization of seed reserves during germination and early seedling growth of two sunflower cultivars. Journal of Applied Botany and Food Quality, v.89, p.217-222, 2016. https://doi.org/10.5073/JABFQ.2016.089.028

GONÇALVES, E.P.;FRANÇA, P.R.C.; VIANA, J.S.; ALVES, E.U.; GUEDES, R.S.;LIMA, C.R. Substrate moisture and temperature in germination of Parkia platycephala Benth. seeds. Ciência Florestal, v.25, n.3, p.563-569, 2015. https://doi.org/10.5902/1980509819607

HOEHNE, L.; SCHNEIDR, F.A.; STULP, S.; TISCHER, J.S.; SANTOS, F. Avaliação das técnicas de determinação de nitrogênio por cromatografia iônica (IC) e por teor de nitrogênio total (TN) por quimiluminescência. Tecnológica, v.20, n.1, p.09-13, 2016. https:// doi.org/10.17058/tecnolog.v20i1.6230

HOOKS, M.A.; ALLEN, E.; WATTIS, J.A.D. Modelling the peroxisomal carbon leak during lipid mobilization in Arabidopsis. Biochemical Society Transactions, v.38, n.5, p.1230-1233, 2010. https://doi.org/10.1042/BST0381230

LOAYZA-CABEZAS, S.; RODRIGUEZ-TREJO, D.A.; HERNÁNDEZ-ACOSTA, E.; SUÁREZ, J.A. Effect of light, temperature and scarification on the germinative capacity and initial growth of Myroxylon balsamum (L.) Harms. Revista Caatinga, v.31, n.2, p.415-423, 2018. https://doi.org/10.1590/1983-21252018v31n218rc

LOPES, L.S.; GALLÃO, M.I.; BERTINI, C.H.C.M. Mobilization of reserves during germination of Jatropha seeds. Revista Ciência Agronômica, v.44, n.2, p.371-378, 2013. https://doi.org/10.1590/S1806-66902013000200021

MAGUIRE, J.D. Speed of germination aid in selection and evaluation for seeding emergence and vigor. Crop Science, v.2, p.176-177, 1962. https://doi.org/10.2135/cropsci1962.0011183X000200020033x

MARCOS-FILHO, J. Fisiologia de sementes de plantas cultivadas. Londrina, Brasil: ABRATES, 2015. 660p.

MCCREADY, R.M.; GUGGOLZ, J.; SILVEIRA, V.; OWENS, H.S. Determination of starch and amylose in vegetables: application to peas. Analytical Chemistry, v.22, n.9, p.1156-1158, 1950. https://doi.org/10.1021/ac60045a016

MELO, M.F.V.; GONÇALVES, L.O.; RABBANI, A.R.C., ÁlVARES-CARVALHO, S.V.; PINHEIRO, J.B.; ZUCCHI, M.L.; SILVA-MANN, R. Populations of Erythrina velutina Willd. at risk of extinction. Genetics and Molecular Research, v.14, n.3, p.10298-10307, 2015. https://doi.org/10.4238/2015.August.28.15

OLIVEIRA, G.M.; MATIAS, J.R.; RIBEIRO, R.C.; BARBOSA, L.G.; SILVA, J.E.S.; DANTAS, B.F. Germination of seeds of Caatinga native tree species at different temperatures. Scientia Plena, v.10, n.4, p.01-06, 2014. https://ainfo.cnptia.embrapa.br/digital/bitstream/ item/108750/1/Barbara-3-2014.pdf

ÖNDER, S.; TONGUÇ, M.; GÜVERCIN, D.; KARAKURT, Y. Biochemical changes stimulated by accelerated aging in safflower seeds (Carthamus tinctorius L.). Journal of Seed Science, v.42, e202042015, 2020. http://dx.doi.org/10.1590/2317-1545v42227873

PACHECO, M.V.; MATTEI, V.L.; MATOS, V.P.; SENA, L.H.D.M. Germination, and vigor of Dimorphandra mollis Benth. seeds under different temperatures and substrates. Revista Árvore, v.34, n.2, p.205-213, 2010. https://doi.org/10.1590/S0100-67622010000200002

REIS, L.P.; BORGES, E.E.L.; SOUZA, G.A.; BRITO, D.S. Relationships between substrate and the mobilization of reserve with temperature during seed germination of Ormosia coarctata Jack. Journal of Seed Science, v.42, e202042017, 2020. http://dx.doi. org/10.1590/2317-1545v42223509

RODRIGUES, D.R.; SILVA, A.F.; CAVALCANTI, M.I.P.; ESCOBAR, I.E.C.; FRAIZ, A.C.R.; RIBEIRO, P.R.A.; FERREIRA NETO, R.A.; FREITAS, A.D.S.; FERNADES-JÚNIOR, P.I. Phenotypic, genetic and symbiotic characterization of Erythrina velutina rhizobia from Caatinga dry forest. Brazilian Journal of Microbiology, v.49, n.3, p.503-512, 2018. https://doi.org/10.1016/j.bjm.2017.09.007 
SANTOS, M.M.; BORGES, E.E.L.; ATAÍDE, G.M.; PIRES, R.M.O.; ROCHA, D.K. Enzyme activity in the micropylar region of Melanoxylon brauna Schott seeds during germination under heat stress conditions. Journal of Seed Science, v.42, e202042009, 2020. http:// dx.doi.org/10.1590/2317-1545v42229988

SILVA, H.A.; OLIVEIRA, D.F.A.; AVELINO, A.P.; MACÊDO, C.E.C.; BARROS-GALVÃO, T.; VOIGT, E.L. Salt stress differentially regulates mobilisation of carbon and nitrogen reserves during seedling establishment of Pityrocarpa moniliformis. Plant Biology, v.21, n.6, p.1110-1118, 2019. https://doi.org/10.1111/plb.13017

SILVA, M.L.M.; ALVES, E.U.; BRUNO, R.L.L.; SANTOS-MOURA, S.S.; SANTOS-NETO, A.P. Germinação de sementes de Chorisia glaziovii O. Kuntze submetidas ao estresse hídrico sob diferentes temperaturas. Ciência Florestal, v.26, n.3, p.999-1007, 2016. https://www. redalyc.org/pdf/534/53447685028.pdf

SORIANO, D.; OROZCO-SEGOVIA, A.; MÁRQUEZ-GUZMÁN, J.; KITAJIMA, K.; BUEN, A. G.; HUANTE, P. Seed reserve composition in 19 tree species of a tropical deciduous forest in Mexico and its relationship to seed germination and seedling growth. Annals of Botany, v.107, n.6, p.939-951, 2011. https://doi.org/10.1093/aob/mcr041

SORIANO, D.; ALVARADO-LÓPEZ, S.; ZÚÑIGA-SÁNCHEZ, E.; OROZCO-SEGOVIA, A.; GAMBOA-DEBUEN, A. Analysis of nitrogen seed reserves of ten tree species of the tropical dry forest. South African Journal of Botany, v.97, p.149-153, 2015. https://doi. org/10.1016/j.sajb.2015.01.003

SOXHLET, F. Die gewichtsanalytische Bestimmung des Milchfettes. Dingler's Polytechnisches Journal, v.232, p.461-465, 1879. http:// dingler.culture.hu-berlin.de/article/pj232/ar232136

TESFAY, S.Z.; MODI, A.T.; MOHAMMED, F. The effect of temperature in moringa seed phytochemical compounds and carbohydrate mobilization. South African Journal of Botany, v.102, p.190-196, 2016. https://doi.org/10.1016/j.sajb.2015.07.003

ZHANG, J.; SIEMANN, E.; TIAN, B.; HUANG, W.; DING, J. Differences in seed properties and germination between native and introduced populations of Triadica sebifera. Journal of Plant Ecology, v.13, n.1, p.70-77, 2020. https://doi.org/10.1093/jpe/rtz048

ZHAO, M.; ZHANG, H.; YAN, H.; QIU, L.; BASKIN, C.C. Mobilization and role of starch, protein, and fat reserves during seed germination of six wild grassland species. Frontiers in Plant Science, v.9, p.1-11, 2018. https://doi.org/10.3389/fpls.2018.00234 use, distribution, and reproduction in any medium, provided the original work is properly cited. 